\title{
Developing Ecology and Environment Learning Materials of Scientific Literacy Skills and Local Potencial for Indonesia Students
}

\author{
${ }^{1}$ Dr.Binari Manurung, ${ }^{1}$ Verronicha Crysty, ${ }^{1}$ Syarifuddin, ${ }^{2}$ Anggi Tias Pratama \\ ${ }^{1}$ Department of Biology Education, Postgraduate Program, Universitas Negeri Medan \\ ${ }^{2}$ Department of Biology Education ,Universitas Islam Negeri Sumatera Utara
}

\begin{abstract}
Indonesian students' scientific literacy skill is still low. It caused by the availability of scientific literacy learning material and textbook are limited and also rare developed based on local potencial, especially for ecology and environment topics. The research aimed to develop a learning material on ecology and environment topics based on scientific literacy and local potential of North Sumatera-Indonesia which is feasible empirically. The feasibility of learning material is obtained through the validation by scientific literacycontent experts, design expert, assessment from biology teacher and students responses. Borg and Gall model was used in this research. However, this study is solely limited to preliminary field testing. Data validation was analyzed descriptively qualitative. The research result showed that according to scientific literacy-content experts, the feasibility of learning material was very feasible, in which the feasibility based on science as a body of knowledge has an average score $93.75 \%$, whereas science as a way of investigation $87.50 \%$, science as a way of thinking $95.31 \%$ and for interaction of science technology and society (STS) 92.50\%. The feasibility of learning material's design corresponded to the design expert was very feasible with $91.43 \%$ as well. Result of biology teacher assessment on learning material was $93.75 \%$ (very feasible). Students' response to the preliminary field individual testing was $80.35 \%$ (feasible), small group trial $84.52 \%$ (very feasible) and large scale group $91.38 \%$ (very feasible).
\end{abstract}

Keywords: Scientific literacy, ecology and environment learning material, local potencial, North SumateraIndonesia

\section{INTRODUCTION}

The $21^{\text {st }}$ century learning in science and technology sector, students need to be equipped with the $21^{\text {st }}$ century skills to ensure their competitiveness in the globalization era. The skills of $21^{\text {st }}$ century learnings which are: digital age literacy, inventive thinking, effective information, communication and high productivity (Greenstein, 2012). Scientific literacy is one of the skills required in digital age literacy. Miller (2002), who has been involved in assessing scientific literacy for over three decades, emphasizes the importance of "civic scientific literacy" in a modern society that relies heavily on technology. He believes that $21^{\text {st }}$ century society requires a public with knowledge about scientific and technological issues for the democratic process to function properly. Scientific literacy plays an important role in human daily lives. Promotion of scientific literacy has been recognized as a major goal of science education in the world (BouJaoude, 2002; National Research Council [NRC], 1996; Zembylas, 2002). Educators agree that scientific literacy should be nurtured as early as possible (Barton, 1994; Bybee, 1997).

Indonesian students' scientific literacy based on PISA surveys in 2015 had taken $66^{\text {th }}$ rank from 72 participants (OECD, 2016). The data showed that Indonesian students only achieve score about 400 constantly from year to year, which means students' scientific literacy still at the beginner level. In addition to the core of literacy, students also need to acquire research skills. Among other things, they need to know is how to access and find book through the library article, note taking and integrate secondary sources, determine the reliability of data, read maps and graphics, visual understanding of scientific, capturing the type of information conveyed by various system representations, distinguishing between fact and fiction, fact and opinion, construct argument and monitor evidence. Students also need to develop technical skills. They need to know how to log on, find information, using a variety of programs, focus on the camera, edit the recording, do the basic programming and so on (Jenkins, 2007). 


\section{Dr.Binari Manurung et al.}

The results of the observations conducted in North Sumatra Indonesia showed that biology learning of senior high school (SMA) on topics ecology and environment has not been developed of learning materials, and yet contained four components of scientific literacy. Another fact was the biology text book has not based on local potencial in North Sumatra and students had not got learning materials which available today contain issues that close to students' daily lives and learning biology in schools should not be linked to the real environment around them. Whereas in biology textbook in Canada, Texas, Mexico and Thailand (Feedman, 2009; Miller \& Levine,1998; Veeravatnanond et al,2001) have highlight the example of real environment that known by students and bring a very positive impact on students' scientific capabilities in interpret information, solve problems, create appropriate decisions, accommodate change, and achieve new understandings.

Students are able to make connections between what they learn in classroom and what they see in daily life (Chamnay et al, 2008). Furthermore, Adisenjaya (2008) and Ariska (2015) had reported that most of biology textbook in high school in Indonesia nowadays are not completely developed based on scientific literacy aspects. Chiapetta et.al (1991a\&b) suggested that there were four components to developed scientific literacy, such as: science as a body of knowledge, science as a way of investigating, science as a way of thinking, and interaction of science, technology and society (STS). Keller \& Suzuki (2004) stated that students' attention could be emerged by using various learning strategies, media, and materials. It is also necessary for learners to perceive the instructional requirements to be consistent with their goals, compatible with their learning styles and connected to their past experiences. It could help students to get relevance for their learning (Driscoll, 1994, Keller \& Suzuki, 2004, and Hodges, 2004).

The use of local potential in learning process is useful to train student's ability in socialize and problem-solving skills (Ahmadi et.al.2012). In addition, the use of local potential in accordance with a curriculum and syllabus gives freedom to each school to consider the potential of school and the surrounding area in learning process (Sajidan, 2013).

North Sumatra has resources, biodiversity that are very important and potential. It has $181,860.65 \mathrm{~km}^{2}$ of its total area, consist of $71680.68 \mathrm{~km}^{2}$ land area and the $110,000.65 \mathrm{~km}^{2}$ marine area (Badan Pusat Statistik, 2015). The geomorphology of North Sumatra is flat to undulating near the coast and rolling to mountains in the upland of Bukit Barisan Mountains. The geomorphology of these regions affects the rainfall pattern, leading to high local variation rainfall distribution (Pieteret al., 2003). It is maked this province rich of in ecosystem such as rice field, palm oil plantation, fruit and vegetable garden, lake ecosytem, marine ecosystem, mangrove ecosystem, etc. North Sumatera also rich of cultures and has some historical sites. These potential can be optimized through the availability of learning materials for ecology and environment topics based on North Sumatera ecosytem characteristic.

Based on the explanation above, it is necessary to conduct developed a learning material on ecology and environment topics based on scientific literacy and local potencial of North Sumatera-Indonesia. According to Kemdikbud (2014), the existing activities on the learning material with a scientific literacy can encourage and inspire students to be able to understand, implement, and develop ways of thinking rationally. This study aim was to carry out with the objective of assessing the feasibility of scientific literacy ecology and environment learning material based on local potential of North Sumatera-Indonesia that has been developed according to scientific literacy -content experts, design expert, biology teacher and students in Senior High School. The process and product of this reserach are expected to learning material based local potencial on North Sumatra - Indonesia had been feasible.

\section{Materials \& Methods}

\subsection{Research Design}

This research and development used Borg and Gall modification model (Gall et al., 2003) which comprised the step of (1) Identifying learning needs; (2) Product planning which include field survey and study in many ecosystem in North Sumatera (rice field, palm oil plantation, lake toba, vegetable and fruit garden, mangrove, etc.) in order to collect local potencial of North Sumatera for learning material composition; (3) Designing preliminary product; (4) Preliminary product development; (5) Preliminary product field testing; (6) Main product revision; (7) Product main Field testing; (8) 
Operational product revision; (9) Product operational field testing; and (10) Final product revision. However this study was limited simply for preliminary field testing. In order to reach this purpose, the learning material scientific literacy ecology and environment topics based on local potencial of North Sumatera-Indonesia has been developed and validated by content and design experts, biology teachers review and students response or perception.

\subsection{Study Samples}

Product development was started on February 2016 and preliminary field testing was carried out on May 2016 to know the feasibility of product. The preliminary field testing was carried out in SMA Negeri 6 Binjai (State Senior High School) Jl. A. R. Hakim No. 66A, Sub-District of Binjai, North Sumatera. The sample preliminary field testing was used individual, small sample, and large sample.

\subsection{Instruments}

Research data was collected by using questionnaire instrument. Instrument for content expert review consist of 56 questions related to scientific literacy aspect and local potencial availability on this product, instrument for design expert consist of 27 questions related to product design and presentation, whereas instrument for biology teacher review consist of 16 questions and 14 question for students response through this product feasibility.

The data primary was collected used a point 4 Likert scale. The responses to each statement of a four scale that was 1 (bad/ not feasible) ; 2(not good/less feasible); 3 (good/feasible); 4 (excellent/very feasible). The respondents will give a number of each item on questionnaire based on the established criteria. Data validation from the questionnaire response from teachers and students were analyzed descriptively qualitative.

The feasibility of learning material was obtained through validation by scientific literacy-content experts to assess feasibility of content based on science as a body of knowledge, science as a way of investigation, science as a way of thinking, interaction of STS, design expert to assess feasibility of learning material design, assessment of biology teacher and students' responses to learning material developed.

\section{RESUlTS \& DisCUSSION}

\subsection{Results}

The results of research and development had which comprised the step of :

\section{Collect Information about Learning needs}

It is used by a questionnaire instruments consist of learning needs problem on school, learning material, local potential on North Sumatra, scientific literacy. The results of these activities showed that related to ecology and environment's learning has not been developed, and yet contained four components of scientific literacy.

\section{Product Planning}

The result of these activities showed that the formated of learning materials, the presentation component of learning material, and teaching material content.

\section{Product Design}

The results of these activities showed that format of learning material designed was started from determining paper size, layout, colour, selecting font and font size.

\section{Preliminary Product Development}

The result of the product development stages was the realization of planning stage. The Draft of finishing product then validated to the expert and reviewers will gain ratings and feedback for improvements. The results of validation will help to make revision of draft product.

\section{Preliminary Field Testing}




\subsubsection{Draft Assesment Based on Scientific Literacy-Content Expert}

The results of research and development that content expert based on scientific literacy can be seen at figure 1.

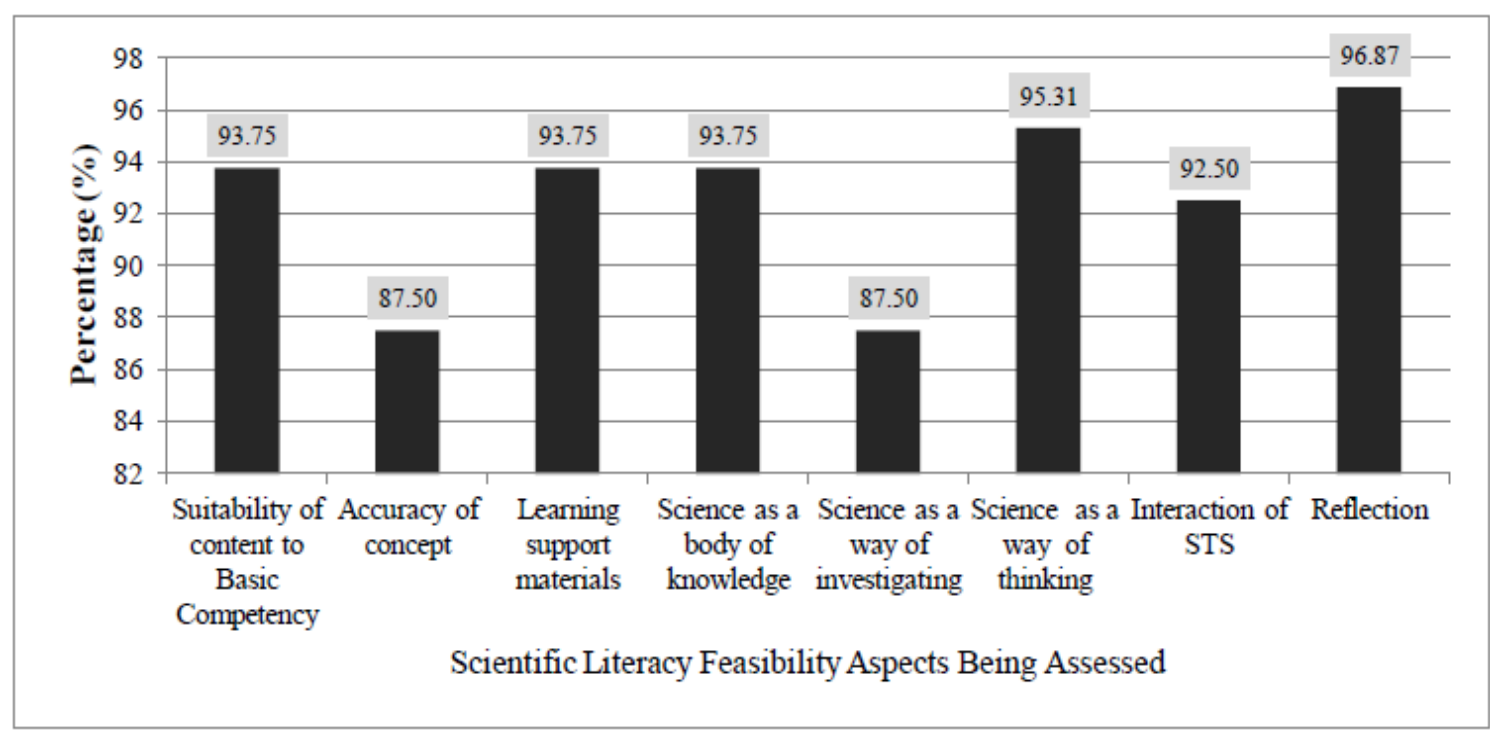

Figure1. The graph result of Percentage Content Experts Assesment for Scientific Literacy Ecology and Environment Learning Material

Figure 1 shows that the value of percentage content experts indicators was, namely: science as a body of knowledge has $93.75 \%$ (very feasible), science as a way of investigating has $87.50 \%$ (very feasible), science as a way of thinkinghas $95.31 \%$ (very feasible), interactionof STS has $92.50 \%$ (very feasible), sustainability of content to basic competenyhas $93.75 \%$ (very feasible), accuracy of concept has $87.50 \%$ (very feasible), learning support material reached has $93.75 \%$ (very feasible) and reflection has $96.87 \%$ (very feasible).

The results feasibility of product's presentation can be seen at figure 2. There are four sub-component as very feasible: presentation techniques, presentation of learning, completeness of presentation and presentation of North Sumatera's local potential that are the hallmarks of learning materialsdeveloped. Learning materials presentation techniques included in the criteria of "very good" (91.07$100 \%$ ). This shows that the product has been written in the appropriate sequence and interconnected, and assisted with the use of good language.

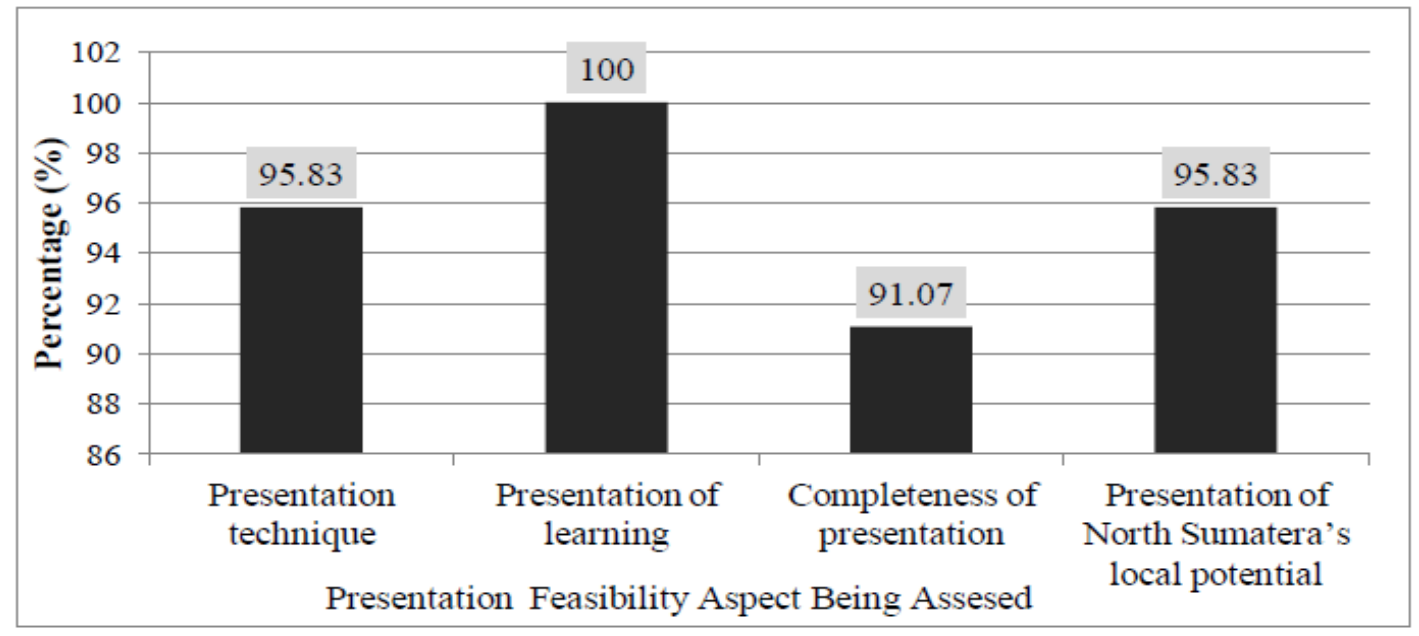

Figure2. The graph Percentation of Scientific Literacy Learning Material on Ecology and Environment Topics Based on North Sumatera-Indonesia Presentation

\subsubsection{Draft Assessment Based on Design Experts}

The results of draft Assessment based on design expert can be seen in Table 1 and at Figure 3. Table 1 shows that the average score was $91.43 \%$ and it categorized as very feasible. 
Developing Ecology and Environment Learning Materials of Scientific Literacy Skills and Local Potencial for Indonesia Students

Table1. Feasibility assesment of design expert to learning materials scientific literacy on ecology and environment topics based local potential of North Sumatera-Indonesia

\begin{tabular}{|c|c|c|c|c|c|c|}
\hline Component & Sub-component & $\begin{array}{l}\text { The number of } \\
\text { item }\end{array}$ & $\begin{array}{l}\text { Design } \\
\text { Validator }\end{array}$ & $\begin{array}{l}\text { Total } \\
\text { Score }\end{array}$ & $\%$ & Criteria \\
\hline Book's format & Size & 3 & 11 & 11 & 91.67 & Very Feasibe \\
\hline \multirow{3}{*}{ Cover's design } & Cover layout & 3 & 10 & 10 & 83.33 & Very Feasibe \\
\hline & Cover typography & 4 & 14 & 14 & 87.50 & Very Feasibe \\
\hline & Cover ilustration & 3 & 10 & 10 & 83.33 & Very Feasibe \\
\hline \multirow{3}{*}{$\begin{array}{l}\text { Book's Content } \\
\text { design }\end{array}$} & Arrangement/ content layout & 6 & 20 & 20 & 83,33 & Very Feasibe \\
\hline & Typography & 5 & 20 & 20 & 100 & Very Feasibe \\
\hline & Content ilustration & 3 & 11 & 11 & 91.67 & Very Feasibe \\
\hline \multicolumn{2}{|c|}{ Total/ Average } & 27 & 96 & 96 & 91.43 & Very Feasible \\
\hline
\end{tabular}

Figure 3 shows that the assesment of design aspect feasibility in book's format, namely: learning material format has $91.67 \%$ (very feasible), cover design has $86.54 \%$ (very feasible) and content design has $91.07 \%$ (very feasible).

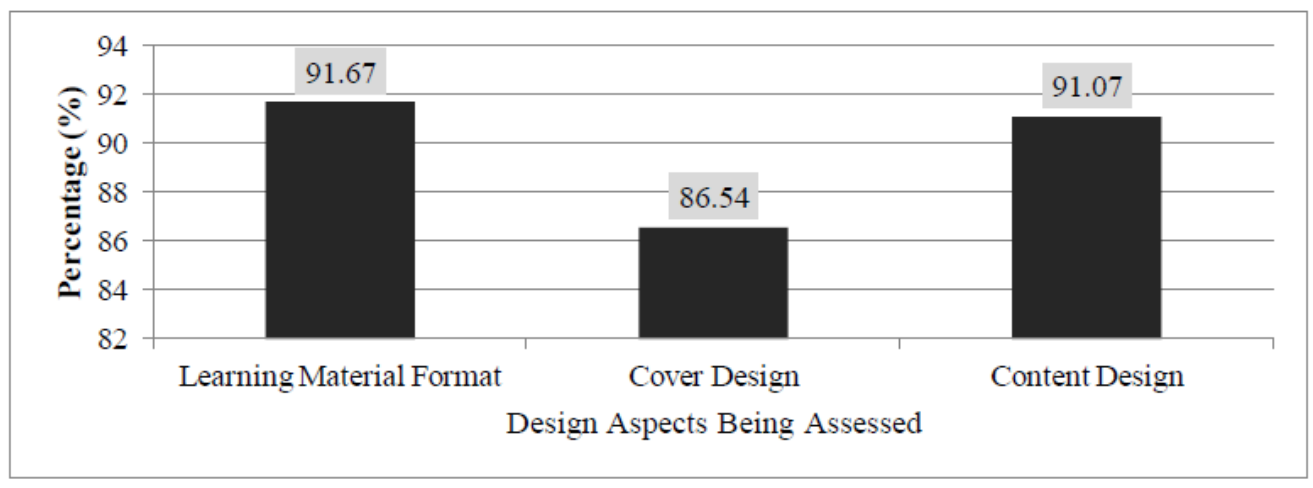

Figure3. The graph of Percentage of Design Experts Assessment for scientific literacy ecology and environment learning material.

\subsubsection{Draft Assessment Based on Biology Teachers Assesment and Students Response}

The results of draft assessment based on biology teachers asssement and students response can be seen in Table 2 and at Figure 4. Table 2 shows that the average score was $94.27 \%$ and it categorized as very feasible.

Table2. Percentage of Biology Teachers Assesment to learning material

\begin{tabular}{|c|c|c|c|c|c|c|}
\hline \multirow{2}{*}{ No } & \multirow{2}{*}{ Indicators } & \multicolumn{3}{|c|}{ Biology Teachers } & \multirow{2}{*}{$(\%)$} & \multirow{2}{*}{ Category } \\
\hline & & 1 & 2 & 3 & & \\
\hline 1 & Learning objective & 4 & 3 & 4 & 91.67 & Very Feasible \\
\hline 2 & Appropriate to students' development level & 4 & 4 & 4 & 100 & Very Feasible \\
\hline 3 & The use of term and image/picture & 4 & 3 & 3 & 83.33 & Very Feasible \\
\hline 4 & Presentation of teaching materials & 4 & 4 & 4 & 100 & Very Feasible \\
\hline 5 & Provide benefits for teachers and students & 4 & 4 & 4 & 100 & Very Feasible \\
\hline 6 & Opportunity for independentlearning and group & 3 & 4 & 4 & 91,67 & Very Feasible \\
\hline 7 & $\begin{array}{l}\text { Motivate students to communicate, interact and } \\
\text { collaborate }\end{array}$ & 4 & 3 & 3 & 83.33 & Very Feasible \\
\hline 8 & Invite students to think holistically \&analitically & 4 & 3 & 4 & 91.67 & Very Feasible \\
\hline 9 & Stimulate students to think critically & 3 & 4 & 4 & 91.67 & Very Feasible \\
\hline 10 & Easily understood language & 4 & 4 & 3 & 91.67 & Very Feasible \\
\hline 11 & The material in accordance with ecologists principle & 4 & 3 & 4 & 91.67 & Very Feasible \\
\hline 12 & Presenting concrete examples & 4 & 4 & 4 & 100 & Very Feasible \\
\hline 13 & Be based on scientific literacy & 4 & 4 & 4 & 100 & Very Feasible \\
\hline 14 & Suitable example tothe daily life & 4 & 4 & 4 & 100 & Very Feasible \\
\hline 15 & $\begin{array}{l}\text { Presents case/ phenomena in surrounding } \\
\text { environment of North Sumatra }\end{array}$ & 4 & 4 & 4 & 100 & Very Feasible \\
\hline 16 & Facilitate self-learning students & 3 & 4 & 4 & 91.67 & Very Feasible \\
\hline & Total Score/ Average & 61 & 59 & 61 & 94.27 & Very Feasible \\
\hline
\end{tabular}


Figure 4 shows that the Students response to learning material, namely: personal/individual has $80.35 \%$, small group has $84.52 \%$, and large scale group has $91.38 \%$. Student response showed the learning material categorized very feasible.

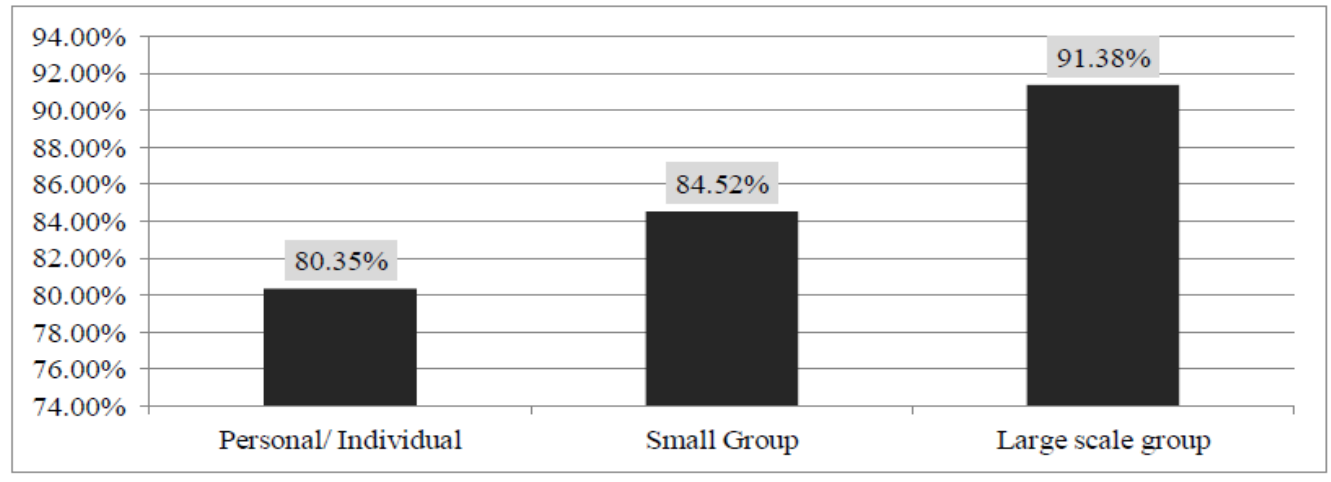

Figure4. The Graph of Students response to learning material

\subsection{Discussion}

Based on the above findings showed that feasibility of learning material was very feasible. The results of this research is in line with the statement of Trianto (2010) and Nisak \& Susantini (2013) which stated a good learning material should be has didactic (content) and construction (linguistic), whereas the secondary requisite is techniques (writing, picture and performance)

All sub-component of scientific literacy-content involved the suitability of content to core and basic competence; the accuracy of concept; the learning support materials based on local potencial of North Sumatra; science as a body of knowledge; science as a way of investigating; science as a way of thinking; interaction of STS and reflection have fulfilled the criteria "very good" or "excellent". This is because in the preparation of product developing refers to the learning objectives and a description of the material that has been in accordance with core competencies and basic competence in Indonesian curicullum (Kemendikbud, 2013), as well as the requirements for the preparation of learning resources are good. According to Kariem et al., (2013), preparing or designing the learning resource must be considered with the curriculum.

The learning materials development was arranged by fulfilled all the requirement for a good standard learning material based on Kemdikbud (2013) standards. In this case, it begins by analyzing the curriculum, drawing up a map of the needs of learning material, specifying the topic and title of learning material which will be developed, and then set to write draft of learning materials.

The learning material product has fulfilled four components of scientific literacy in accordance with Chiapetta et al (1991), such as: (1) science as a body of knowledge; by describing and explaining the truth of facts, concepts, principles and procedures, based on the concepts and theories applicable thus the content can be justified scientifically on ecology and environment topics in biology course at grade X SMA, (2) science as a way of investigating by answering questions about ecology using graph, table, calculating and critical thinking in solving problems related to ecology and environment. It was available in bio-review and mini-lab on product, (3) science as away of thinking; by giving illustration, diagram to find out the relationship, interaction also cause-effect of phenomenon related to ecology and environment in North Sumatera (as rice field, palm oil plantation, fruit and vegetable gardens, river and lake ecosystems, marine and mangrove ecosystems), (4) interaction of STS; by providing information related to topics of science technology and society, updated issues which displayed on connecting biology and daily life also bio-link on this product and it has reflection questioning which could help students to reflect their knowledge into a better life. Furthermore, theories and concepts of material and activities in the product were acquired from several textbooks, empirical research obtained from various journals and news on the web site. Therefore, the feasibility of material content in these developed products could be used as learning materials on ecology and environment topics in biology course at grade X SMA in North Sumatera.

The systematic of writing on product rated as excellent because it presented coherence and systematically, the connection between sentences, paragraphs and concepts were very good. Besides, the learning materials were easier to understand since the language used was in accordance with the level of student's development as well as the phrases which were clear and not ambiguous. Trianto 
(2010) stated the language used in a learning materials should be clear, simple, and in accordance with students' abilities. This was consistent with student responses on preliminary field testing of product which stated that language used in learning materials was suitable to students education level and sentences structure were clear and simply to understand.

Learning materials were able to motivate learners to respond to the material. Yet it was encouraged students to think critically, and creatively, active, communicative, interactive and involved students to find out knowledge through activities. Supporting presentation included was very feasible. Title in product adapted to the material. This result is also line with Prastowo (2011) who stated the title should be in accordance with basic competency or subject matter that should be achieved by students.

According to design expert, the design and layout of learning materials considered as attractive and able to captive the interest for students because its design was looks nice and not overdone, involved updated issues about the local potential of North Sumatera that associated to learning materials that can attract the attention of students. This was consistent with the responses given by the students during individual/personal, small and big group testing in which students expressed that the design of product was very interesting. In this case, Trianto (2010) stated appearance is very important in learning materials, because it was captive the interest of students at the beginning before straightforward to the contents.

Learning materials also provide student identity column and another main component as well as table of contents, instructions for use product for teachers and students, introduction, supporting information, mini-lab activities, closure, reference, glossary and the identity of the author. This is also in line with Prastowo (2011) and Kemdikbud (2014) stated that structure of learning materials is generally load titles, basic competencies to be achieved, the time required to complete, equipment or materials required to complete the task, a brief description, the work step, tasks to be performed, references and glossary.

The feasibility of learning materials design included in the criteria of very feasible. This was obtained from front type, size, easy to read, understand and printing in an appropriate size. Kemdikbud (2014) stated that in design a printed learning material very important to consider the stimulant/attractiveness and readability. It is strongly supported by the results of expert validation on design component and typography of cover and content which qualifies as very feasible.

This learning materials was packed with a good packaging, cover paper using art paper 260gr and laminated so it looks shiny and waterproof, paper of learning materials use A5 size with 80 gr paper that are not transparent when used back and forth. This is also supported by the results of expert validation of the format design of product that are included in the criteria of "very good".

In addition, the pictures quality used learning material was clear, interest, clarify the description, and representative to the concept. Komalasari (2011) stated a figure or photo-graph can give a real capture which shows the real object, give meaningful learning and learning accurately than lectures technique and it can stimulate students' thinking skills. Thus, this learning material will give a positive influence on learning activities, especially improve student motivation. This is also supported by the results of expert design validation to illustration on learning materials contents which categorized as "very feasible" category.

Based on the considering assessment from 40 students and 3 biology teachers, the feasibility of learning material were very feasible. It had been caused a good packaging, original image and the update issues. This result was line with Brown (2001) stated using the good image in learning material to increase students attention and interesting. Additionally, the learning materials was compiled based on scientific approach. Students' activities organized by the scientific approach, independently construct their understanding on biological material. A real learning experience will make students easy to remember concepts as stated by Komalasari (2011) that involves the students will make them remember the concept of $90 \%$ and reduce the occurrence of misconceptions.

\section{Conclussion}

It is concluded that learning material on ecology and environment topics based on scientific literacy and local potencial of North Sumatera is very good of feasible to used in teaching ecology and environmental topics in grade X SMA. Where the feasibility of the content based on science as a body 
of knowledge has an average score $93.75 \%$ (very good), whereas science as a way of investigation $87.50 \%$ (very good), science as a way of thinking $95.31 \%$ (very good), interaction of science, technology and society $92.50 \%$ (very good). Feasibility of learning material's design that has been developed based on design expert is also very good with a percentage score of $91.43 \%$. Result of biology teacher assessment on learning material on ecology and environment topics based on scientific literacy was developed with $93.75 \%$ (very good). Students' response to the preliminary field testing individual testing was $80.35 \%$ (good), small group trial $84.52 \%$ (very good) and large scale group $91.38 \%$ (very good).

\section{REFERENCES}

[1] Adisendjadja. Y.H. (2008). Analisis Materi Pengajaran Ilmiah berdasarkan Literasi Ilmiah sebagai Bimbingan untuk Memilih Bahan Ajaran yang Baik dalam Biologi [Analysis of Scentific Teaching material based on Scientific Literacy as Guidance to Choose A Good Teaching Material in Biology]. Bandung: Pend.Biologi FMIPA UPI.

[2] Ahmadi, I., et al. (2012). Developing Education Based on Local Potency (In Indonesian). Jakarta: Prestasi Pustaka.

[3] Ariska, R. N. (2015). Peran konstruksi latihan Biologi dalam buku teks sains, seks siswa, dan tingkat sekolah pada prestasi Uji PISA di Binjai [The roles of Biology excercise construction in students science textbook, students' sex, and school level on PISA Test achievement in Binjai]. (Unpublish Thesis). Medan: Postgraduate Program, State University of Medan.

[4] Barton, D. (1994). Literacy: An introduction to the ecology of written language. Cambridge, MA: Blackwell.

[5] BouJaoude, S. (2002). Balance of scientific literacy themes in science curricula: the case of Lebanon. International Journal of Science Education, 24/2, 139-156.

[6] Bybee, R. W. (1997). Achieving scientific literacy_From purposes to practices. Portsmouth, NH:Heinemann.

[7] Badan Pusat Statistik Indonesia (BPS). (2015). Retrieved from https://www.bps.go.id/.

[8] Brown, James W. 2001. AV Instruction : Technology, Media and Methods. United State of America : McGraw-Hill.

[9] Burckhardt, P (2014). On the Factors Influencing Performance of Indonesian Students in PISA.Article.

[10] Chamnay, K., et.al. (2008). Making Biology Learning Relevant to Students: Integrating People, History, and Context into College Biology Teaching. CBE—Life Sciences Education. 7, 267278.

[11] Chiapetta, E.L., et al., (1991a).Procedures for Conducting Content analysis of Science Textbooks, Texas: Department of Curriculum and Instruction, Houston.

[12] Chiappetta, E.L, et al., (1991b). A Quantitative Analysis of High School Chemistry Textbooks for Scientific Literacy Themes and Expository Learning Aids".Journal of research in science teaching, 28/10, 939-951.

[13] Driscoll, M. P. (1994). Psychology of learning for instruction. Needham Heights, MA: Allyn \& Bacon.

[14] Freedman, B. (2009).Environmental Science: A Canadian Perspective (5th Edition). Pearson Canada.

[15] Gall, M.D., Gall, J.P and Borg, W.R. (2003). Educational Research: An Introduction 7th Edition. Boston Allyn and Bacon.

[16] Greenstein, L. (2012). Assesing 21 st Century Skill, A Guide To Evaluating Mastery and Authentic Learning. USA: Corwin A Sage Company.

[17] Hodges, C. (2004). Designing to motivate: motivational techniques to incorporate in e-learning experiences. The Journal of Interactive Online Learning, 2 (3).

[18] Jenkins. H. (2007). Confronting the Challenges of Participatory Culture - Media Education for the $21{ }^{\text {st }}$ Century (Part Two). Nordic Journal of Digital Literacy. 
Developing Ecology and Environment Learning Materials of Scientific Literacy Skills and Local Potencial for Indonesia Students

[19] Kariem, F., et al., (2013). Pengembangan Materi Pembelajaran TIK berdasarkan Pembelajaran Berbasis Proyek [The Development of TIK Learning Material based on Project Based Learning]. Invotec, 9/2:117-128.

[20] Keller, J. M., \& Suzuki, K. (2004). Learner motivation and e-learning design: a multinationally validated process. Journal of Educa-tional Media, 29/3.

[21] Kemdikbud. (2013). Kurikulum 2013 SMA/MA (Madrasah Aliyah) [Curriculum 2013 of High School (SMA)/ Madrasah Aliyah (MA)]. Jakarta: Directorate General of Primary and Secondary Education.

[22] Kemdikbud. (2014). Pembelajaran Scientific [Scientific Learning]. Ministry of Education and Culture. Retrieved from: kemdikbud.go.id.

[23] Komalasari, K. (2011). Pembelajaran Kontekstual melalui Konsep dan Aplikasi [Contextual Learning through Concept and application]. Bandung: PT Refika Aditama.

[24] Miller, J. (2002). Civic Scientific Literacy: A Necessity in the 21st Century. FAS Public Interest Reports, 5/1, 3-6.

[25] Miller \& Levine. (1998). Biology, The Living Things. The Prentice Hall, inc.: Texas.

[26] National Research Council (NRC). (1996). National science education standards. Alexenderia. VA: National Academic Press.

[27] Nisak, K., Susantini, E. (2013). Pengembangan Perangkat Pembelajaran IPA Terpadu Tipe Connected pada Materi Pokok Sistem Eksresi Untuk kelas IX SMP [The Development of Integrated IPA Learning Kit Connected Type on Basic Matter of Excretory System For class IX SMP], Jurnal Pendidikan Sains e-Pensa, 1/1.

[28] OECD (2016) PISA 2015, PISA Results in Focus.www.oecd.org/pisa/pisa-2015-results-infocus.pdf.

[29] Pieter, J.H., et.al. 2003. Economic valuation of the Leuser National Park on Sumatra, Indonesia. Ecological Economic, 44/1: 43-46.

[30] Prastowo, A. (2011). Panduan Kreatif dalam Menciptakan Bahan Ajar Inovatif [Creating an Exciting and Fun Learning Methods]. Jogjakarta: Diva Press.

[31] Rustaman, N.Y. (2010). Literasi Sains Siswa Indenesia [Indonesian Student' Scientific Literacy]. Article.

[32] Sajidan (2013). Pembelajaran dengan Pendekatan Ilmiah Implementasi Kurikulum 2013 [Learning Sciences with Scientific Approach to the Implementation of Curriculum 2013], Seminar Nasional XI Pendidikan Biologi FKIP UNS.

[33] Trianto. (2010). Merancang Model Pembelajaran Inovatif-Progresif [Designing InnovativeProgressive Learning Model]. Jakarta: Kencana Prenada Media Group

[34] Veeravatnanond, V., et al., (2001). The applications of local wisdoms and resources in environmental development; education; and community economy in Nakhonnayok province. Bangkok: Srinakharinwirot University Journal.

[35] Zembylas, M. (2002). The global, the local, and the science curriculum: a struggle for balance in Cyprus. International Journal of Science Education, 24/5, 499-520. 


\section{AUTHORS' BIOGRAPHY}

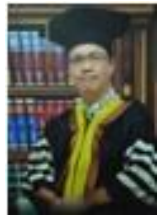

Dr.Binari Manurung, Drs, M.Si, rer.nat, is a professor in bioecology of the Biology Department at Graduate and Postgraduate Programe of Universitas Negeri Medan (Medan State University), Medan, North Sumatera, Post code 20221, Indonesia.He obtained his Bachelor Degree in Biology Education from IKIP Medan, his Master Degree in Biology from ITB Bandung and his Doctor Degree in biology from Martin-Luther University of Halle-Wittenberg, Halle (Saale), Germany.

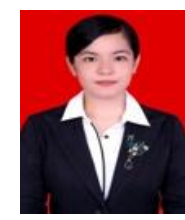

Verronicha Crysty, S.Pd., M.Pd., is a biology education postgraduate student at Postgraduate Programe of Universitas Negeri Medan (Medan State University), Medan, North Sumatera, Post code 20221,Indonesia.She obtained her Bachelor and Master Degrees in Biology Education from Universitas Negeri Medan. She is also a teacher of biology in Senior High School.

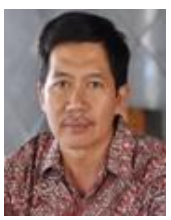

Syarifuddin, Drs, M.Sc, PhD, is a lecturer at Graduate andPostgraduate Programe of Universitas Negeri Medan (Medan State University), Medan, North Sumatera, Post code 20221 Indonesia. He obtained his Bachelor Degree in Biology Education from IKIP Medan, his Master Degree in Biology from Mc Gill University, Montreal, Canada and his Doctor Degree in Environmental Management and Ecology from LaTrobe University, Melbourne, Australia.

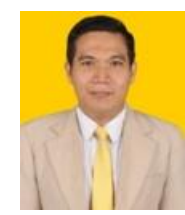

Dr.Anggi Tias Pratama, S.Pd, M.Pd, is a lecturer at Graduate Department of Biology Education, Faculty of Tarbiyah and Teacher's Training Universitas Islam Negeri Sumatera Utara, Medan, North Sumatera, Post code 20221, Indonesia. He obtained his Bachelor and Master Degrees in Biology Education from Universitas Negeri Medan, his Doctor Degree in Biology Education from Universitas Negeri Malang. 